\title{
On booze: a representation of the roaring twenties in The Great Gatsby
}

\author{
Jenison Alisson dos Santos ${ }^{1}$ \\ Caio Antônio de Medeiros Nóbrega Nunes Gomes² \\ Elisa Mariana de Medeiros Nóbrega ${ }^{3}$
}

\begin{abstract}
Fitzgerald is considered by many to be the spokesperson of the 1920's post-World War I, offering his readers a distinctive look into the Golden Age of the U.S.A.. This article focuses on F. Scott Fitzgerald's masterpiece The great Gatsby (2001) and its representation and criticism of the historical context in which author and novel are inserted: the Jazz Age or the Roaring Twenties of the United States of America. For this purpose, our critical framework is based on Bloom's (2006) and Heise's (2001) studies on the subject, targeting a pertinent dialogue with Fitzgerald' s work. As a result of our articulation between the critical framework and the corpus, we were able to recognize how the American author managed to express in his work a keen perception of the social conventions and the morals of the Jazz Age, of both the overt (the parties and the ostentation) and the covert aspects (the emptiness of that society and the unspoken post-war dread) of his time.
\end{abstract}

Keywords: North American literature. F. Scott Fitzgerald. The great Gatsby. Jazz age.

\section{A bebedeira: uma representação dos anos loucos da década de 20 em O Grande Gatsby}

Resumo: Fitzgerald é considerado o porta-voz da década de 1920, pós Primeira Guerra Mundial, oferecendo aos seus leitores uma visão distinta da Era de Ouro dos Estados Unidos da América. O presente artigo é voltado para a obra prima de F. Scott Fitzgerald, O grande Gatsby (2001), e a representação e crítica do contexto histórico no qual autor e obra estão inseridos: a Era do Jazz ou os Loucos Anos Vinte dos Estados Unidos. Para tanto, as argumentações para a análise pactuam com a crítica literária feita por Bloom (2006) e Heise (2001) sobre a temática, buscando produzir um diálogo pertinente com a obra de Fitzgerald. Como consequência do alinhamento entre o respaldo crítico e o corpus do artigo, podemos perceber como o autor norte-americano foi competente ao expressar em seu escrito uma visão substancial das convenções sociais e das morais da Era do Jazz, uma visão que perpassa ao mesmo tempo os aspectos explícitos (as festas e a ostentação) e implícitos (o vazio da sociedade e o silencioso temor pós-guerra) de seu tempo.

Palavras-chave: Literatura norte-americana. F. Scott Fitzgerald. O grande Gatsby. Era do jazz.

\footnotetext{
${ }^{1}$ Graduando em Letras pela Universidade Federal da Paraíba. E-mail: jenison.alisson@gmail.com.

${ }^{2}$ Mestrando pelo Programa de Pós-Graduação em Letras (PPGL) da Universidade Federal da Paraíba.

E-mail: caioamnobrega@gmail.com.

${ }^{3}$ Doutora em História pelo Programa de Pós-Graduação em História (UFPE) e professora do Programa de Pós-Graduação em Literatura e Interculturalidade (PPGLI - UEPB). E-mail: elisammn@hotmail.com.
} 


\section{INTRODUCTION}

The present article aims to analyze how Fitzgerald's historical background and life experiences influenced substantially the writing of The great Gatsby, his magnum opus, and how the novel can enlighten the reader as to what was like to live in the author's time, such a chaotic moment in American history.

During the 1920's, the United States of America underwent a significant shift on its financial and civil settings after succumbing to near bankruptcy due to the effects of World War I. As a result, the American citizens went through a period of unconstrained consumerism, which consequently led to the subversion of the conventions and sense of morality of the society as a whole. Fitzgerald's acclaimed novel, The great Gatsby (2001), originally published in 1925, may be considered a singular characterization of the Roaring Twenties, for the American author, by witnessing the rise and fall of this period directly, is able to illustrate the dissonance amidst customary and tarnished sense of morality by highlighting the characters and their characterizations - dreams, strong desires for success and commodity, disenchantments -, to ultimately demonstrate that the American Dream was a generalized illusion unrestricted to societal groups and individuals.

\section{THE ROARING TWENTIES}

It comes as no surprise that F. Scott Fitzgerald was pointed to be the spokesperson of the Roaring Twenties - or as he would like to call, The Jazz Age -, for he was an active member of the society from which he came, particularly regarding its cultural dimension; the author was keen to register this distinct period in his writings, which are underlined with a poignant critique of the vicissitudes of the time. His unique insight into the era of chaos and commotion is what made him 
one of the great names of the American. And what better literary piece to exemplify Fitzgerald's vision of the particular time than his masterpiece, The great Gatsby (2001)? In his novel, the American author denounces the lavishly extravagant way of life of the U.S. citizens during the Jazz Age - an age in which people would purposelessly consume, solely to be ultimately blindsided by the Great Depression that hit the country by the end of the decade.

Similarly to The great Gatsby's (2001) narrator, Nick Carraway, Scott Fitzgerald was persuaded by the new way of life that was established in the country after World War I. Even though Fitzgerald was immersed in a society of indiscriminate consumerism, he was able to see through the curtains of the conventions of the Roaring Twenties and, on the other side of this illusionary paradise, he noticed the deceitfulness and moral desolation of such a society.

This sociological paradox occurred due to the impact that World War I had caused throughout America. During the war, the United States were experiencing a financial stagnation which led the country to change its dynamics, economically-wise (McNEESE, 2010). Factories and businesses alike faced a great percentage of cutbacks - manufacture, plantation and animal income, and export decreased - and, as a result, a near commercial bankruptcy took over.

By the end of the war, however, when the mass production of weaponry was no longer needed, the economic focus of the nation shifted towards improving its own financial status (PIETRUSZA, 1998). A few years after the war was over, the United States began to prosper and a cultural phenomenon of consumerism took place. The ever expanding consumption of goods obtained rightful recognition amongst Americans as a way to reward themselves for surviving the financial crisis installed in the country during the war period (McNEESE, 2010), and it was fueled by the production of new technologies in large scale interconnected with accessible payment methods. Not having to worry about the prospect of going to war any time soon and with a more financially comfortable life, the citizens of the United States 
were enthusiastic to spend their money on the up-to-the-minute luxuries advertised by the media, creating a culture of ill-advised greediness. This deceitful sense of wealth and substantiality originated the American Dream.

The American Dream is the systematization of the American citizens' ideology that, with the good omen of fortune and stability, the people of the United States would be able to establish themselves with a "better, richer, happier life for all our citizens of every rank [...]" (ADAMS, 2012, xx). According to Adams (2012, xiii), "[f]rom the start, $[\ldots]$ the American dream was not about the elimination of social class distinctions, but for mobility through those ranks based on hard work." However, to be able to grant this almost utopian lifestyle, some compromises should be made - autonomy, rivalry, struggle, and commitment being some of them. And if we can see Jay Gatsby's trajectory as an indication, some people were willing to take shortcuts to achieve their objectives, resorting to illegal practices.

Not only does The great Gatsby (2001) embody the spirit of the Roaring Twenties, but it also offers the reader a sneak peek behind the curtains of a society moved by alcohol, good music, parties, and indulgence. The author's background story, along with his special talent with words - for Fitzgerald believed that, when it comes to writing literature, "You've got to sell your heart, your strongest reactions, not the little minor things that only touch you lightly [...]. But literature, even light literature, will accept nothing less [...]" (FITZGERALD, 1995, n.p.) -, is what makes The great Gatsby (2001) an outstanding portrait of the American 1920's.

\section{THE MAN BEHIND THE (HI)STORY}

It goes without saying that the life of an author is highly likely to play a part on his or her creative thinking process. One could even say that it is possible to make parallels between their lives and works. That does not mean that a literary piece should be taken as an autobiographical one. Rather, authors are known to use 
elements of their lives and experiences when creating the fictional worlds we see in their writings.

Booze, ambition, literature, Princeton and his wife Zelda (BRUCOLLI, 1997) were Francis Scott Key Fitzgerald's (September 24th 1896 - December 21st 1940) main fuel to build his literary legacy. From poems to songs and plays (BLOOM, 2006), writing was not a strange concept to Fitzgerald. Fitzgerald was born in St. Paul, Minnesota, son of a salesman named Edward and a housewife named Mollie. Fitzgerald's works began to receive notoriety since his school years, when a detective short story of his was published (and praised) in the school newspaper, when he was 13 years old.

After completing high school education, the soon-to-be acclaimed author went to Princeton University with intentions to master his craft, but it was of no use, given that he dropped out to join the army (BLOOM, 2006). Afraid he would die in the war (even though he had never been to one), he wrote what is known to be his first novel, The romantic egotist, but it was rejected by the publisher (BRUCOLLI, 1997). Transferred to Alabama, Fitzgerald met the woman who turned his life upside down: the belle Zelda Sayre. Even though they seemed to fall for each other, Zelda allegedly refused to engage Fitzgerald for he was not wealthy enough to provide for her. Similarly to his main character in The Great Gatsby (2001), Fitzgerald was compelled by his emotions towards a woman who embodied everything he yearned for, even though she drove him towards becoming deeply absorbed into everything Fitzgerald would later come to repudiate.

Determined to sweep Zelda off her feet, he came back home at St. Paul on September 1919, after a summer of heavy drinking, and rewrote his now twice rejected novel mentioned above and changed its title to This side of paradise, which was finally published in 1920 and became an instant bestseller. The book "traces the career aspirations and love disappointments of Amory Blaine" (BRUCOLLI, 1997, 
n.p.) and it portrays the lifestyle of a post-World War I youth driven by selfindulgence and social status.

His new-found fame caused the desired effect and Zelda finally accepted to marry him in that same year, a week after his literary debut. They had their only child a year later, a girl named Scottie.

After his overnight notoriety, Fitzgerald became a full-time and acclaimed writer. Following his debut novel, a collection of short stories was released in the same year (first published in editions of The Saturday Evening Post magazine) named Flappers and Philosophers. According to The New York Times, "'Flappers and Philosophers' represents the triumph of form over matter, just as, on the whole, Mr. Fitzgerald's novel, 'This Side of Paradise', represented the triumph of matter over form."

Subsequent to the release of Flappers and Philosophers, amidst all the scandals, wild parties and heavy drinking, Fitzgerald wrote a series of books and short stories portraying the infamous Roaring Twenties, giving him the honorary position of spokesperson for the "Lost Generation". These works include The beautiful and the damned (1922), Tales of the jazz age (1922), The vegetable (1923), The great Gatsby (1925), All the sad young men (1926), Tender is the night (1934), Taps at reveille (1935), The last tycoon (1941), and The crack up (1945) (BLOOM, 2006).

Throughout his literary production, the author constructs a raw, loud and unapologetic picture of the Roaring Twenties, from its early days, to its pinnacle and its unavoidable end. Scott Fitzgerald took over the literary scene at that time, not only because of his natural, effortless writing style, but also because of his unique vision of that particular world. Fitzgerald built his legacy by exposing the extravagance and ostentation of that era with a sharp and critical opinion.

Such a deed was possible because the author lived the Roaring Twenties firsthand. He and his wife Zelda had a celebrity status due to Fitzgerald's success, so it was not unusual for them to be seen in the highest social circles. During the 
following decade, Zelda and F. Scott Fitzgerald were at the center of Roaring Twenties cultural scene, and regularly appeared in gossip magazines. Their affairs, their hard partying and their "craziness" were among the favorite topics of gossip conversations. Not everything was bad regarding the Fitzgeralds, though, for they were known to work as hard as they would party.

However, this unrestrained lifestyle took a toll on them in 1930, when Zelda Fitzgerald began suffering a series of nervous breakdowns, which ultimately led her to be admitted in an asylum in 1936. In this period, with the end of the Roaring Twenties due to the crash of the stock market that put an end to the decade-long party, Fitzgerald decided to try his luck in Hollywood as a screenwriter, but the experience did not turn out as well as he hoped, forcing him to go back home to St. Paul, where he died of a heart attack in 1940. Eight years later, Zelda died in a fire in the asylum she had been admitted to, giving an end to the powerful couple of the 1920 's.

Gone, but not forgotten, Scott Fitzgerald left his mark in the world as one of the greatest American writers of all times.

\section{A SNEAK PEEK BEHIND THE SCENES OF THE GREATEST AND LONGEST PARTY OF ALL TIMES}

When one hears about the 1920 's, the images that come to one's mind are bobbed-hair flappers and people dancing the Charleston to the sound of jazz music. We have Fitzgerald to thank for that. The 1920's is also known as The Roaring Twenties, The Economic Boom, The Lost Generation and, of course, The Jazz Age, a term coined by Fitzgerald himself.

It was a profitable moment in the United States, a moment of cultural overflow and social relevance. It was also Fitzgerald's moment. The author had his 
masterpiece, The great Gatsby (2001), published in 1925, a novel that masterly portrays the essence and atmosphere of the period.

Considered one of the greatest pieces of American literature, the novel tells the story of Jay Gatsby, a mysterious man who is determined to restore his romantic relationship with his love from the past, Daisy Fay. The narrative is developed through the perspective of Nick Carraway, Gatsby's neighbor and Daisy's cousin.

The novel paints a perfect picture of the 1920's: its representation of the historical (the end of WWI and the prosperity of the country as a whole) and cultural backgrounds (the music, the fashion, the cars) allows the reader to identify effortlessly the time in which the story was set. Fitzgerald brings to light the extravagant lifestyle and the ever present emptiness and moral desolation that embraced the 1920's (BLOOM, 2006), a period that was particularly (mis)guided by the quest for the American Dream - a dream paved by the prospect of richness and a sense of contentment that came with a promising economic scenario.

One cannot mention the Roaring Twenties and not talk about the praised materialism of such time, established by the concept of the American Dream. People were interested in one and only one thing: economic prosperity. From a luxurious mansion in the East Egg to a trip overseas, money is a recurring theme in The great Gatsby (2001), both as a blessing and a curse. But interestingly enough, all the material prospect, such as Gatsby's "colossal affair" (FITZGERALD, 2001, p. 5) of a house with "period bedrooms swathed in rose and lavender silk and vivid with new flowers, through dressing-rooms and poolrooms, and bathrooms with sunken baths" (FITZGERALD, 2001, p. 58) and "a toilet set of pure dull gold" (FITZGERALD, 2001, p. 59), was not enough to satisfy the characters' urges, just as it was most likely not enough to please people back in the day. According to Heise (2001, p. 49), "The latenight parties in Fitzgerald's fiction, metaphors for the era's purposeless splendor, often dissipate into haunting loneliness." 
When one takes into consideration Tom Buchanan's character, one may perceive that he offers the reader another perspective on the American Dream. Luxury and consumerism play a significant role in his idea of such a dream, but those elements are means to achieve power and control. Tom's sense of supremacy and dominance comes from a mindset that reflects his perception of others in relation to himself, especially those who came from an underprivileged social position. That is made explicit in the text when Tom and Gatsby are having an altercation at the Plaza Hotel about Daisy's affections:

Tom tapped his thick fingers together like a clergyman and leaned back in his chair. "You are crazy!", he exploded. "I can't speak about what happened five years ago because I didn't know Daisy then and I'll be damned if I see how you got within a mile of her unless you brought the groceries to the back door. But all the rest of that's a God-damned lie. Daisy loved me when she married me and she loves me now (FITZGERALD, 2001, p. 84).

One will be able to notice in his speech that Tom treats Daisy as one of his proprieties, neglecting her feelings entirely on the matter, for he is absolutely certain that Daisy loves him. Gatsby may offer her some diversion, but he would not be able to offer her the commodities that Tom's money can buy; ergo, Daisy would never love someone such as Gatsby. Tom Buchanan's perverted sense of morality becomes the embodiment of Daisy's obstacle to achieve true happiness with Gatsby, being also the ultimate reason that drives the protagonist to his death, in a representation of how distorted ethics could emerge from a corrupted understanding of the purpose of the American Dream.

Besides this lavish way of living praised by the wealthy circles of the American society, another aspect that is easily distinguishable amongst those people is a kind of moral decay, that came as a consequence of the frenetic urgency to enrich and spend money. Such an excusable behavior, explicit in Fitzgerald's novel, was 
specially justified if it meant for one to achieve his or her goals, such as to attain a desirable social status. In this sense, Fitzgerald constructed his protagonist, Jay Gatsby, as if to embody this aspect of the Roaring Twenties. The characters who knew Jay Gatsby in all his fame and glory (with his mansion and exorbitant parties) could not imagine that he was once poor, for "[h]is parents were shiftless and unsuccessful farm people [...]" (FITZGERALD, 2001, p. 63). But Gatsby “[...] never really accepted them as his parents at all" (FITZGERALD, 2001, p. 63), which brings the reader to understand that being rejected by Daisy due to his underprivileged background was not his only motivation to succeed in life, for Gatsby also was ashamed of his origins. In order to overcome his humiliating past, Gatsby created a "[p]latonic conception of himself" (FITZGERALD, 2001, p. 63), built on affluence and notoriety. Moreover, to accomplish his aspiration, Gatsby ultimately resorted to a life of crime - alcohol smuggling, or bootlegging -, a common practice at that time, for the U.S. government had prohibited the commercialization of alcoholic beverages. Tom Buchanan uses this piece of information against Gatsby when they are fighting at the Plaza Hotel:

\footnotetext{
"Who are you, anyhow?" broke out Tom. "You're one of that bunch that hangs around with Meyer Wolfshiem - that much I happen to know. I've made a little investigation into your affairs - and I'll carry it further to-morrow." "You can suit yourself about that, old sport." said Gatsby steadily. "I found out what your 'drug stores' were." He turned to us and spoke rapidly. "He and this Wolfshiem bought up a lot of side-street drug-stores here and in Chicago and sold grain alcohol over the counter. That's one of his little stunts. I picked him for a bootlegger the first time I saw him, and I wasn't far wrong." (FITZGERALD, 2001, p. 85)
}

As mentioned before, it was not uncommon for people to make use of illicit ways to enrich and obtain social status. As an author, Fitzgerald chose not to hide such an aspect of the 1920's, but rather expose it on such a light that made it clear 
that himself and a parcel of the community were disillusioned with the concept of the American Dream. According to Cullen,

The problem with the American Dream [...] is that even as Gatsby pursues his dream through instruments of fraud and adultery there is a deeply compelling purity about his ambition, especially given the smug pieties of those around him (hence Nick's sincere pronouncement that Gatsby is "worth the whole damn bunch of them put together"). Rather, the real problem is that any American Dream is finally too incomplete a vessel to contain longings that elude human expression or comprehension (CULLEN, 2004, p. 182).

One may argue that Fitzgerald develops a sense of conscious bias towards the (dis)illusion of the dream: Jay Gatsby ultimately becomes the corrupt representation of the idealist person who allowed himself to be misled by the pursuit of a superfluous, unachievable dream; Tom Buchanan represents the unscrupulous impulse to safeguard his wealth and the comfort it provides, maintaining his social status at all costs.

Finally, it would not be surprising to assume that the excessive greediness and low moral standards of the Roaring Twenties were, in fact, symptoms of an emptiness caused by a mix of emotional shock resulted from the WWI and the effortlessness achieving of objectives (never satisfying) due to the economic prosperity of the country. Fitzgerald did not fail to bring this up, being such a purposelessness the central theme of the book. The existential emptiness filled with meaningless materialism can be easily perceived in Daisy's character. The majority of readers may understand Daisy as a foolish character, but in fact she is far from being foolish or naïve. Reading her most powerful line in the novel, "She [the nurse] told me it was a girl, and so I turned my head away and wept. 'All right,' I said, 'I'm glad it's a girl. And I hope she'll be a fool - that's the best thing a girl can be in this world, a beautiful little fool.'” (FITZGERALD, 2001, p. 13), one may conclude that Daisy is a 
rather clever woman, for she understands that dreams are not always fulfilled and things that seem important at a first glance are actually not so valuable, thus allowing her only to pretend to be a fool and say to herself that everything is fine the awful truth of the 1920's and the core theme of the novel. Such a concept, learned by Daisy after being trapped on a loveless marriage, eludes Gatsby's understanding, for his misconstrued ideal of a happy ending with Daisy led Gatsby to dissociate himself from reality and his sense of integrity. The final events of the novel, when Daisy flees the country with Tom - for Daisy would not take for granted the security and status that Tom Buchanan provided over Gatsby's illicit fortune made as a bootlegger -, leaving no address (FITZGERALD, 2001, p. 104), as if nothing had happened, leaves Nick utterly frustrated and disgusted with those people, that particular lifestyle, and himself. In this sense, the final events of the novel reverberate the general feeling of the American society (including Fitzgerald himself) at the end of the Roaring Twenties.

\section{CONCLUDING REMARKS}

It is remarkable to realize how revealing of the Roaring Twenties - not only its overt aspects, such as the parties and ostentation, but its covert aspects as well, such as the emptiness of that society and the unspoken post-war dread - The great Gatsby (2001) can be. We may also argue that the literary piece crosses significant points and represents aspects of Fitzgerald's life itself. That is because the lifestyle of the Roaring Twenties is embedded in his veins, in his work and in his writing style. It is this fine distinction that allows Fitzgerald to set himself apart from the other writers of that period. In addition to that, we understand that it is the author's sharp perception of his surroundings that makes the reader to be deeply invested both on the plotline and on the history of such a tumultuous time period.

The Roaring Twenties seemed to be an exciting and sophisticated time for the U.S., but upon careful observation the anguish that had been swept under the rug of 


\section{Revista Letras Raras}

ISSN: 2317-2347 - Vol. 7, Ano 4, N0 2 - 2015

the Roaring Twenties' society becomes rather evident. The moral unscrupulousness, the extravagant lifestyle and the emptiness present in the 1920's were captured by Fitzgerald in a perfection similar to that of an oil painting, and immortalized as a masterpiece of worldwide literature.

\section{REFERENCES}

ADAMS, James Truslow. The epic of America. Somerset: Transaction Publishers, 2012.

BLOOM, Harold. Bloom's guide: F. Scott Fitzgerald's the great Gatsby. New York: Chelsea House Publishers, 2006.

BRUCOLLI, Matthew J. A brief life of Fitzgerald. 1997. $<$ http://www.fscottfitzgeraldsociety.org/biography/>. Acessado no dia 9 de Fevereiro de 2014.

CULLEN, Jim. The American Dream: a short history of an idea that shaped a nation. New York: Oxford University Press, 2004.

FITZGERALD, F. Scott. A life in letters. New York: Simon \& Schuster, 1995. . The great Gatsby. Hertfordshire: Wordsworth Editions Ltd, 2001.

HEISE, Thomas. The 'Purposeless Splendor' of the Ideal in the Fiction of F. Scott Fitzgerald. In: BLOOM, Harold (org.). Bloom's biocritiques: F. Scott Fitzgerald. Philadelphia: Chelsea House, 2001.

McNEESE, Tim. Discovering U.S. history: World War I and the roaring twenties, 19141928. Broomall: Chelsea House Publisher, 2010.

PIETRUSZA, David. The roaring twenties. Farmington Hills: Cengage Gale, 1998.

<http://www.nytimes.com/books/00/12/24/specials/fitzgerald-flappers.html>. Acessado no dia 9 de Fevereiro de 2014.

Recebido: em 31 de agosto de 2015 Aceito: em 14 de outubro de 2015 